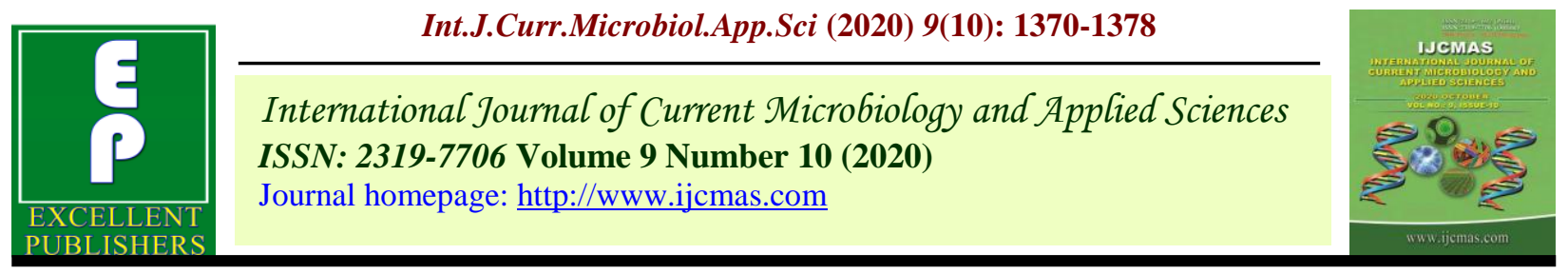

Original Research Article

https://doi.org/10.20546/ijcmas.2020.910.164

\title{
Genetic Parameters of Variation for Seed Yield and its Component Traits in Black Gram (Vigna mungo L. Hepper)
}

\author{
Vikky Kumar*, J. L. Salam, Parfull Kumar, N. C. Mandavi and D.P. Singh
}

S. G. College of Agriculture \& Research Station, IGKV, Jagdalpur (C.G.) 494005, India

*Corresponding author

\begin{abstract}
A B S T R A C T
Black Gram (Vigna mungo L. Hepper) is most prevalent types out of pluses crops 80 genotypes of Black gram collected from Bastar Region (Dantewad, Sukma, Bijapur, Kondagoan, Narayanpur, Kanker districts). The experiment was conducted in Randomized Complete Block Design (RCBD) with two replications comprising two check varieties viz. Indira Urd Pratham and T.U. 94-2.Crop growing spacing 30×10cm during Kharif 2019 in Research cum Instructional Farm of SGCARS Kumhrawand, Jagdalpur, Bastar (C.G.). Analysis of variances indicated presences of significant genetic variability for thirteen biometrical traits in Black Gram genotypes. Highest GCV and PCV estimated for seed yield per plant, plant height $(\mathrm{cm})$, number of primary branches per plant and test weight of thousand seeds. High heritability and genetic advances indicated least influenced of environment on the expression of character and characters governed by additive genes respectively. High heritability accompanied with high Genetic Advance as percent of mean observed for the traits plant height $(\mathrm{cm})$, Test weight of thousand seeds, seed yield per plant $(\mathrm{g})$, harvest index $(\%)$ and petiole length $(\mathrm{cm})$ due to additive gene effect abundant sources provided for improving the traits though section.
\end{abstract}

\section{Introduction}

Black gram [Vigna mungo (L)] belongs to kingdom plantae, division magnoliophyta class magnoliopsida sub class roside, order fabales, family Fabaceae, (alt. Leguminosae) Sub family Papilionaceae, genus vigna species mungo with chromosome number $2 \mathrm{n}$ $=22$ (Cronquist, 1988). Black gram is classified in two groups Vigna mungo var. niger and Vigna mungo var. Virdis, in niger includes varieties which mature early and have black coloured seeds and in virdis includes varieties which mature late and their seeds are smaller and green in colour. Synonym of Black gram is locally known as Urd, Biri and Mash. It is originated in India from wild progenitor Phaseolus sublobatus was found domesticated in south Asian countries. It is an annual erect growing herb with height of 0.3-1.0 m and stem are ribbed and covered by brown hairs. Leaves are trifoliate and dark green covered with profuse purplish small hairs. Leaflets are broad, ovate 
and entire in margins. Flower is clusters of 56 , born on long hair peduncle. They have 5 sepal, 5 petals, 9+1 stamen, and hairs are twisted in style (Ram, 2011). Pods are dehiscent, long and cylindrical (4-6 cm), having 4-10 dark brown/black /dull olive green seed black gram is self pollinated crops.It is mainly grown in India as well as in Myanmar, Pakistan, Bangladesh and Srilanka. Occupying both tropical and sub tropical regions. It has grown over 3.4 million hectare in the world, out of which 2.97 million hectare is grown in India. Black gram contributing $10 \%$ of the total pulse production from $13 \%$ in total area in India (Joshi, 2015). High values of lysine make urd bean an excellent complement to rice in terms of balanced human nutrition (Sakila and Pandiyan, 2018). Nutritive value of urdbean hold protein $26-27 \%$, calcium $-154 \mathrm{mg} / 100 \mathrm{~g}$, fat $-1.4 \%$, phosphorus $-385 \mathrm{mg} / 100 \mathrm{~g}$, Minerals $-3.2 \%$, Iron - $9.1 \mathrm{mg} / 100 \mathrm{~g}$, Fiber-0.9\%, calorific value-347Kcal $/ 100 \mathrm{~g}$, carbohydrate$60 \%$, moisture $10.9 \%$ and vitamins (mg/100gm) $B_{1}, B_{2}$ and Niacine 0.42, 0.37 and 2.0 respectively (Panigrahi et al., 2014). Black gram can be grown on different types of soils from light sandy to heavy clay soils having well drained condition. It should be temperature range between $25^{\circ} \mathrm{C}$ to $35^{\circ} \mathrm{C}$, relative humidity 50 to $85 \%$ and annual rainfall of 600- $1000 \mathrm{~mm}$ for better growth and development. But it grows better on rich black vertisols or loamy soils with a pH6-7. It can withstand acidic soil (down to $\mathrm{pH} 4.5$ ). It is drought tolerant and thus suitable for semi arid areas. Urd is sensitive to saline and alkaline soils (Sharma et al., 2011). In rainfed agriculture, it has special status, as it is an effective soil blinder over all soil conservation and also act as green manuring crop. Black gram is an important food legume with excellent source of good quality protein and having ability to restore fertility of soil though symbiotic nitrogen fixation (Gupta $e t$ al., 2008).
India is larger producer $(25 \%$ of global production), consumer $(27 \%$ of word consumption) and importer (14\%) of pulses in the world. Pulses can be produced with a minimum use of recourses and hence, it becomes less costly even than animal protein. Important states growing black gram in India total area (lakh ha) and production (lakh tonnes) of black gram is 44.78, 28.32 respectively in which Madhya Pradesh (12.03) (8.17), Utter Pradesh (6.44)(3.57), Andhra Pradesh (5.00) (3.29), Rajasthan (4.77) (3.05), Tamilnadu (4.30) (2.74), Maharashtra (3.38) (1.83), Gujarat, (1.97) (1.19), Jharkhand (1.57) (1.39), Orissa (1.09) (0.49) and Other states (3.29) (2.06) respectively (Anon, 2016).

In the year 2018-19 during rabi and 2019-20 during kharif in India area (lack ha) and production (lack tonnes) is 7.629, 26.5, 37.52 and 25.6, respectively (Anon. 2019).In Chhattisgarh black gram area (000 ha) and production $(\mathrm{kg} / \mathrm{ha})$ according to the year wise in 2015-16(154.51) (305), 2016-17(144.94) (320), 2017-18(164.44) (332) occupies respectively (Anon. 2019).

All the varieties developed to date are mainly by single plant selection from locals. There is greater need to increase the yield and quality of this crop by breeding while understanding the genetic makeup of this crop. Hence, it is essential to generate new variability through hybridization. By germplasm exploration superior germplasm's can be identified from these local varieties which can be ultimately used for developing superior lines in breeding programme. Hence looking to the above facts investigation entitled "Diversity analysis in black gram [Vigna mungo (L.) Hepper] genotypes collected from Bastar resign" is being carried out with the objective "to study the genetic variability in black gram for seed yield and its yield related components traits" 


\section{Materials and Methods}

The present experiment entitled "Diversity analysis in black gram [Vigna mungo (L.) Hepper] was conducted at "Research cum Instructional Farm, Shaheed Gundadhoor College of Agriculture and Research Station, Kumhrawand, (Jagdalpur), Indira Gandhi Krishi Vishwa vidyalaya, Raipur (Chhattisgarh)" located at N 19०5'39" longitude E 81 ${ }^{\circ} 59^{\prime} 33^{\prime \prime}$ latitude and at an altitude 553.400 meters above mean sea level (MSL) with an annual rainfall $14.39 \mathrm{~mm}$. The experimental material comprised of eighty two black gram genotypes along with two check varieties Indira Urd Pratham and T.U. 94-2. The experimental material was planted in a Randomized Complete Block Design with two replications during kharif 2019. Each genotype was planted in two rows of 3 $\mathrm{m}$ length $\times 1 \mathrm{~m}$ width having $30 \times 10 \mathrm{~cm}$ spacing between rows and plants. The observations were recorded on five randomly selected plants per replication for each accession. The analysis of variance for different characters was carried out using the mean data through method given by Ponse and Sukhatme (1964).

The phenotypic and genotypic variances and genetic advance were calculated as suggested by Johnson et al., (1955) and Sivasubramanium and Madhavamenon (1973). Genotypic and phenotypic coefficients of variations were estimated by using the formula suggested by Burton and De Vane (1953). Heritability in broad sense for each character was analysed by using the method suggested by Hanson et al., (1956).The coefficient of variation (CV) being a unit less measurement, is a good basis for comparing the extent of variation between different characters with different scales. The genotypic and phenotypic variance was calculated as per the formulae proposed by Burton (1952).Broad sense heritability was computed as "the ratio of genetic variance to the total or phenotypic variance as suggested by Hanson et al., (1956) and expressed as percentage". The expected genetic gain for each character was analyzed by using the following method suggested by Johnson et al., (1955).

\section{Results and Discussion}

Analysis of variance was performed for thirteen quantitative traits including yield and yield attributes of 82 genotypes. From the analysis of variance it was observed that mean sum of squares due to genotypes was significant for all characters at 5\% level of significance under study, thus exhibiting the presence of significant considerable genetic variability for all the traits in the experimental material. The results found were presented in Table 1. These findings are authorization with the finding of Singh et al., (2020), Shalini and Lal (2019), Aftab et al., (2018), Chauhan et al., (2018), Vidya et al., (2018), Bishnoi et al., (2017), Rolaniya et al., (2017), Tank et al., (2017), Jyothsna et al., (2016), Priyanka, et al., (2016), Sohel et al., (2016), Usharani and Kumar (2016), Veeramani et al., (2005) in black gram.

\section{Genetic variability}

The results pertaining to genetic parameters viz., range, mean, genotypic variance, phenotypic variance, phenotypic coefficient of variation, genotypic coefficient of variation, heritability, genetic advance and genetic advance as per cent of mean were calculated to estimate the amount of genetic variability for different characters. The results related to genetic parameters are presented in the Table 2. The data of mean and range reveals the extent of phenotypic and genotypic variability of characters under study. 
Table.1 Analysis of variances for seed yield and its attributing traits in black gram

\begin{tabular}{|c|c|c|c|c|c|c|c|c|c|c|c|c|c|c|}
\hline $\begin{array}{l}\text { Source of } \\
\text { variation }\end{array}$ & $\begin{array}{c}\text { Degrees } \\
\text { of } \\
\text { freedom }\end{array}$ & DFF & NPBPP & NPPP & $\begin{array}{c}\text { PL } \\
(\mathbf{c m})\end{array}$ & PH (cm) & NSPP & DFMP & DM & $\begin{array}{l}\text { PeL } \\
(\mathrm{cm})\end{array}$ & NPPC & HI & $\begin{array}{c}\text { TW } \\
\text { (g) }\end{array}$ & $\begin{array}{c}\text { SYPP } \\
(\mathrm{g})\end{array}$ \\
\hline Replication & 1 & 3.51 & 0.13 & 22.08 & 0.20 & 204.87 & 0.09 & 383.91 & 384.15 & 3.53 & 0.01 & 0.01 & 11.14 & 65.05 \\
\hline Treatments & 81 & $9.15^{* *}$ & $0.42 * *$ & $38.88 * *$ & $0.42 * *$ & $450.39 * *$ & $0.42 * *$ & $20.42 * *$ & $14.91 * *$ & $5.32 * *$ & $0.41 * *$ & $157.34 * *$ & $65.07 * *$ & $130.96 * *$ \\
\hline Error & 81 & 4.18 & 0.03 & 5.69 & 0.10 & 8.96 & 0.12 & 7.11 & 9.77 & 0.67 & 0.10 & 7.34 & 2.17 & 5.75 \\
\hline SE(d) & - & 2.04 & 0.16 & 2.39 & 0.31 & 2.99 & 0.35 & 2.67 & 3.13 & 0.82 & 0.32 & 2.71 & 1.47 & 2.40 \\
\hline C.D. at $5 \%$ & - & 4.08 & 0.33 & 4.76 & 0.63 & 5.97 & 0.69 & 5.32 & 6.23 & 1.63 & 0.64 & 5.40 & 2.94 & 4.78 \\
\hline C.V. (\%) & - & 5.07 & 8.08 & 5.11 & 6.51 & 6.30 & 5.27 & 4.18 & 4.08 & 7.91 & 9.01 & 5.25 & 5.34 & 10.76 \\
\hline
\end{tabular}

*Significant at $5 \%$ level of significance $\mathrm{DFF}=$ Days to 50 percent flowering, $\mathrm{DM}=$ Days to maturity, $\mathrm{PH}=\mathrm{Plant}$ height $(\mathrm{cm}), \mathrm{NPBPP}=\mathrm{Number}$ of primary branches per plant, $\mathrm{NPPP}=$ Number of pods per plant, DFMP= Days to first mature pod, NPPC $=$ Number of pods per cluster, $\mathrm{PeL}=\mathrm{Petiole}$ length $(\mathrm{cm}), \mathrm{PL}=\mathrm{Pod}$ length $(\mathrm{cm}), \mathrm{NSPP}=$ Number of seeds per pod, SYPP= Seed yield per plant $(\mathrm{g}), \mathrm{HI}=$ Harvest index $(\%), \mathrm{TW}(\mathrm{g})=$ Test weight of 1000 Seed. 
Table.2 Genetic parameters of variation for seed yield and its component traits in black gram

\begin{tabular}{|c|c|c|c|c|c|c|c|}
\hline \multirow[t]{2}{*}{ Characters } & \multirow[t]{2}{*}{ Mean } & \multicolumn{2}{|l|}{ Range } & $\mathbf{C V}$ & \multirow[b]{2}{*}{$\operatorname{PCV}(\%)$} & \multirow{2}{*}{$\begin{array}{c}\mathbf{h}^{2} \mathbf{b s} \\
(\%)\end{array}$} & \multirow{2}{*}{$\begin{array}{c}\text { GA as \% } \\
\text { mean }\end{array}$} \\
\hline & & Min & Max & $\operatorname{GCV}(\%)$ & & & \\
\hline DFF & 40.34 & 34.50 & 45.00 & 3.91 & 6.40 & 37.28 & 4.91 \\
\hline NPBPP & 2.02 & 1.00 & 3.20 & 22.00 & 23.44 & 88.10 & 42.53 \\
\hline NPPP & 46.67 & 41.40 & 56.40 & 8.73 & 10.12 & 74.47 & 15.52 \\
\hline PL (cm) & 4.83 & 3.53 & 6.03 & 8.27 & 10.52 & 61.74 & 13.38 \\
\hline PH (cm) & 47.52 & 24.60 & 101.51 & 31.26 & 31.89 & 96.10 & 63.13 \\
\hline NSPP & 6.54 & 5.62 & 7.81 & 5.96 & 7.95 & 56.08 & 9.19 \\
\hline DFMP & 63.75 & 57.50 & 73.00 & 4.05 & 5.82 & 48.34 & 5.80 \\
\hline DM & 76.65 & 70.50 & 83.00 & 2.09 & 4.58 & 20.83 & 1.97 \\
\hline PeL (cm) & 10.35 & 7.04 & 13.77 & 14.74 & 16.73 & 77.63 & 26.74 \\
\hline NPPC & 3.57 & 2.50 & 4.60 & 10.93 & 14.16 & 59.56 & 17.38 \\
\hline HI ( $\%)$ & 51.58 & 26.32 & 69.32 & 16.79 & 17.59 & 91.09 & 33.01 \\
\hline TW of 1000 Seeds (g) & 27.62 & 20.70 & 47.22 & 20.31 & 21.00 & 93.54 & 40.46 \\
\hline SYPP (g) & 22.28 & 11.06 & 41.53 & 35.51 & 37.10 & 91.59 & 70.00 \\
\hline
\end{tabular}

$\mathrm{GCV}=$ Genotypic coefficient variance, $\mathrm{PCV}=$ Phenotypic coefficient variance, $\mathrm{h}^{2}$ bs $=$ Heritability in broad sense, DFF $=$ Days to 50 percent flowering, DM= Days to maturity, $\mathrm{PH}=$ Plant height $(\mathrm{cm}), \mathrm{NPBPP}=$ Number of primary branches per plant, $\mathrm{NPPP}=$ Number of pods per plant, $\mathrm{PeL}=\mathrm{Petiole}$ length $(\mathrm{cm}), \mathrm{PL}=\mathrm{Pod}$ length $(\mathrm{cm}), \mathrm{NSPP}=$ Number of seeds per pod, NPPC=Number of pods per cluster, DFMP=Days to first mature pod, HI= Harvest index $(\%), \mathrm{SYPP}=\mathrm{Seed}$ yield per plant $(\mathrm{g}), \mathrm{TW}=$ test weight of 1000 seeds. 
Results obtained from these components of genetic parameter indicate presence of abundant amount of genetic variability in the material under present investigation. These findings are in authorisation with the findings on the reports of Chowdhury et al., (2020), Singh et al., (2020), Sathees et al., (2019), Chauhan et al., (2018), Priya et al., (2018), Verma et al., (2018), Sinha et al., (2018), Panigrahi et al., (2014), Singh et al., (2014), Sowmini and Jayamani (2013).

Data obtained from the experiment showed high PCV and GCV have in seed yield per plant $(37.10 \%)(35.51 \%)$, plant height (31.89\%, 31.26\%), number of primary branches $(23.44 \%, 22.00 \%)$ and 1000 seed weight $(21.00 \%, 20.31 \%)$ respectively. Moderate PCV and GCV have in harvest index $(17.59 \%, 16.79 \%)$, petiole length $(16.73 \%, 14.74 \%)$ and number of pods per cluster $(14.16,10.93)$ respectively. Moderate PCV and low GCV values recorded both traits pod length $(10.52 \%, 8.27 \%)$ and number of pods per plant $(10.12 \%, 8.73 \%)$. Low PCV and GCV for days to maturity $(4.58 \%$, $2.09 \%)$, days to first mature pod $(5.82 \%$, $4.05 \%)$, days to $50 \%$ flowering $(6.40 \%$, $3.91 \%)$ and number of seeds per pod $(7.97 \%$, $5.96 \%)$. if the genetic coefficient of variance (GCV) is higher than phenotypic coefficient of variance (PCV) it indicate that there is little influence of environment on the expression of character. Selection for improvement of such characters will be regarding. when less than PCV as compared to GCV the Apparent variation is not only due to genotype but also due to the influence of environment. These approximations of the current study were authorized with the outcomes of Chowdhury et al., (2020a), Singh et al., (2020), Chaithany et al., (2019), Shalini and Lal (2019), Singh et al., (2019), Sathees et al., (2019), Veni et al., (2019), Aftab et al., (2018), Chauhan et al., (2018), Priya et al., (2018), Sinha et al., (2018), Tank et al., (2018), Verma et al.,
(2018), Bishnoi et al., (2017), Mahesha and Lal (2017), Hemalatha et al., (2017), Deepshika et al., (2014), Panigrahi et al., (2014), Sowmini and Jayamani (2013).

High heritability coupled with high genetic advance indicated presence of additive gene action in these traits viz. plant height $(96.10 \%$, $63.13 \%$ ), test weight of 1000 seeds $(93.54 \%$, $40.46 \%)$, seed yield per plant $(91.59,70 \%)$, harvest index $(91.09 \%, 33.01 \%)$, number of primary branches per plant $(88.10 \%, 42.53 \%)$ and petiole length $(77.63 \%, 26.74 \%)$ additive gene action is pronounced in the expression of these characters, early generation selection would be effective in breeding program (Singh and Narayanan, 2015). High heritability coupled with low genetic advance it is indicated non-additive gene action, the high heritability is being exhibited due to favorable influence of environment rather than genotypes and selection for such traits may not be rewarding. Low heritability accompanied with high genetic advance it reveals that the character is governed by additive gene effects. The low heritability accompanied with low genetic advance for the characters viz. days to first mature pod $(48.34 \%, 5.80 \%)$, days to $50 \%$ flowering $(37.28 \%, 4.91)$ and days to maturity $(20.83 \%$, $1.97 \%$ ) it indicates that the character is highly influenced by environmental effect and selection would be ineffective.

Moderate heritability was recorded for the characters pod length (61.74\%), number of pods per cluster $(59.56 \%)$ and number of seeds per pod $(56.08 \%)$. The findings of present study were in agreement with the findings of Sathees et al., (2019), Sushmitharaj et al., (2018), Aftab et al., (2018), Chauhan et al., (2018), Mahesha and Gabriel (2017), Rolaniya et al., (2017), Anand et al., (2016), Sohel et al., (2016) and Panigrahi et al., (2014). 


\section{References}

Aftab N., Lal, G.M., Sheera A., Bose, N. C., and Tripathi A.M., (2018) evaluation of genetic variability in black gram (Vigna mungo L. Hepper). Journal of Plant Development Sciences Vol. 10 (8): 445452.

Anand G., Anandhi K., and Paulpandi V.K., (2016). Genetic variability, correlation and path analysis for yield and yield components in $\mathrm{F}_{6}$ families of Green gram (Vigna radiata (L.) Wilczek) under rainfed condition. Electronic Journal of Plant Breeding, vol.7 (2).

Anonymous. (2019). Production of black gram in India. Agriculture market intelligence center, PJTSAU, Directed of economic and statistics, ministry of agriculture and farmer Welfare, Govt. of India September, p. 1.

Anonymous (2016). Prospects of Pulses-2016 - NFSM www.nfsm.gov.in > Status Paper > Pulses.

Arulbalachandran, D., Mullainathan, L., Velu, S. and Thilagavathi, C. (2010). Genetic variability, heritability and genetic advance of quantitative traits in black gram by effects of mutation in field trial. African J. Biotech., 9 (19): 27312735.

Bishnoi, A., Gupta, P., Meghawal D.R. and Lal G.M. (2017). Evaluation of genetic variability and heritability in blackgram (Vigna mungo (L.) Hepper) genotypes Journal of Pharmacognosy and Phytochemistry. 6(4): 493-496.

Burton, G. N. (1952). Quantitative inheritance in grasses. Grassland Cong., 1: 277 285.

Chauhan, S., Mittal R. K., Sood, V.K., and Patial, R., (2018) evaluation of genetic variability, heritability and genetic advance in black gram [Vigna mungo (L.) Hepper] Legume Research an International Journal LR-4002 [1-6].
Cronquist, A. (1988). The evolution and classification of flowering plants $2^{\text {nd }}$ ed., New York botanical garden pr Dept., P. 555.

Deepshika, Lavanya GR, Kumar S. (2014). Assessment of genetic variability for yield and its contributing traits in black gram. Trends in Biosciences. 7:28352838.

Ecocrop (FAO) permits the identification and comparison of more than 2300 plant species on environmental requirements in all agro-ecological settings of the world. Textual information also includes a brief description of the species, for yield and yield components in Black gram (Vigna mungo (L.) Hepper). Int. J. Chem. Stu. 7(1): 22402243

Gandi R., N. Shunmugavalli and Muthuswamy (2018). Genetic Variability, Heritability and Genetic Advance Analysis in Segregating Population of Black Gram [Vigna mungo (L.) Hepper] Int.J.Curr.Microbiol.App.Sci 7(2): 703709.

Gupta S K, Souframanien J and Gopal, K. T. (2008). Construction of a genetic linkage map of black gram (Vigna mungo L. Hepper) based on molecular markers and comparative studies. Genome 51: 628-637.

Hanson, C.H., Robinson, H.F. and Comstock, R.E. (1956). Biometrical studies of yield in segregating population of Korean Lespedeza. Agro. J. 48: 268272.

Hemalatha K, Lal SS, Lal GM. (2017). Study on genetic variability and correlation in black gram (Vigna mungo L. Hepper). Journal of Pharmacognosy and Phytochemistry. 6:674-676.

Johnson, H. W. and Bernard, R.L. (1955). Soybean genetics and breeding, Advances in Agronomy 14: 149- 
221Journal of Life Science 2(1): 61-65.

Joshi, M. (2015). The text book of field crops. $1^{\text {st }}$ Ed., Ashoke, K. Ghose PHI Learning private limited, Rimjhim House, 111 New Delhi -110092, p. 132.

Jyothsna S., Patro T.S.S.K, Ashok S., Sandhya, R. Y. and Neeraja B. (2016). Character association and Path analysis of Seed Yield and its Yield Components in Black gram (Vigna mungo (L.) Hepper) International Journal of Theoretical \& Applied Sciences, 8(1): 12-16.

Mahesha, H.S. and Lal, Gabriel, M. (2017) Studies on Genetic Diversity in Black Gram (Vigna mungo L. Hepper) Germplasm. Int. J. of Adva. Bio. Res. VOL.7 (3): 426-434.

Malik M. F. A., Shahid I. A. and Shahid N., (2008). Comparative Study of Quantitative Traits and Association of Yield and its Components in Black Gram (Vigna mungo) Genotypes. Asian Journal of Plant Sciences, 7: 26-29.

Panigrahi, K., Baisakh, B., Kar, M. and Mohanty, A. 2014. Research Note Genetic divergence in mutants and land races of black-gram [Vigna mungo (L.) Hepper] from Odisha. Electronic Journal of Plant Breeding, 5(3): 567572.

Ponse, V.G. and Sukhatme, P.V. (1967).Statistical methods for Agricultural Research Workers. III edition, ICAR, New Delhi.

Priyanka S., Rangaiah, S. and Showkath, B. B. M. (2016). Genetic Variability Estimates of Quantitative and Qualitative Traits in Black Gram. International Journal of Agriculture Sciences Volume 8 pp.-1821-1824.

Ram, H.H. (2011) Crop Breeding and biotechnology, Kalayani Publiser New Delhi, 11: 284-293.

Rolaniya D. K., Jinjwadiya M. K., Meghawal D. R. and Lal G.M., (2017) Studies on genetic variability in Black gram (Vigna mungo L. Hepper) germplasm. Journal of Pharmacognosy and Phytochemistry; 6(4): 1506-1508.

Sakila, M. and Pandiyan, M. (2018). Realization of facts and profiteering of black gram through different breeding methods. Int. J. Chemi. Studies.6 (4): 3359-3369.

Sathees, N., D. Shoba, S. Saravanan, S. Merina Perm Kumari and Arumugam Pillai, M. (2019). Studies on Genetic Variability, Association and Path Coefficient Analysis in Black Gram (Vigna mungo L. Hepper). Int.J.Curr.Microbiol.App.Sci. $\quad$ 8(06): 1892-1899.

Shalini C.H. and Lal, G.M. (2019). Genetic variability, correlation and Path coefficient analysis for yield and yield component in Black Gram (Vigna mungo L. Hepper). Pharma Innovation Journal, 8(6): 65-68.

Singh K, Gautam RK, Singh PK, Kumar N, Swain S. (2014). Estimation of genetic variability and association analysis in the indigenous landraces of black gram of Andaman islands. Vegetos, 27:113122.

Singh, L., Ashok K., Satinder K. and Ranjit K. G. (2020). Genetic Variability, Heritability and Genetic Advance as Mean for Yield and Yield Contributing Traits in Urdbean (Vigna mungo L. Hepper). Int.J.Curr.Microbiol.App.Sci. 9(04): 2778-2786.

Sinha S., SB Mishra, Chandan Kishore and SS Pandey (2018). Genetic variability, correlation and path analysis in Intraand inter-specific hybrids of Vigna mungo L. Hepper. Journal of Pharmacognosy and Phytochemistry SP1: 180-184

Sivasubramanian $\mathrm{J}$ and Madhavamenon (1973). Genotypic and phenotypic variability in rice. Madras Agric. J. 12: 
15-16.

Sohela, M. H., Miaha, M.d. R., Mohiuddinb, S. J., Islamc, A. K. M. S., Rahmand, Md. M. and Haquee, Md. H. (2016). Correlation and path coefficient analysis of Black gram (Vigna mungo L.). J. Biosci. and Agric. Res., 7(02): 621-629.

Sowmini.K and Jayamani. P. (2013). Genetic variability studies for yield and its component traits in RIL population of black gram (Vigna mungo (L.) Hepper). Electronic Journal of Plant Breeding, 4(1): 1050- 1055.

Sushmitharaj, D.V., Shoba, D. and Arumugam Pillai, M. (2018). Genetic variability studies is in blackgram (Vigna mungo) (L.) Hepper) with reference to YMV resistance. International Journal of current microbiology and applied sciences, 6:2489-2856.

Tank, H. K., PP Sharma, KK Nagar, L.L. Bairwa and DR Meghawal Genetic variability and heritability studies in blackgram [Vigna mungo (L.) hepper] (2018). International Journal of Chemical Studies, 6(6): 642-646.

Usharani, K.S., and Kumar, C.A. (2015). Induced polygenic variability using combination treatment of gamma rays and ethyl methane sulphonate in black gram (Vigna mungo (L.) Hepper). African Journal of Biotechnology. 14(20):1702-1709.

Varma, P. N., Baisakh, B. and Swain, D.(2018) Study on Genetic Variability, Correlation and Path Coefficient Analysis for Yield and Component Traits in Green gram Int.J.Curr.Microbiol.App.Sci., (2018) 7(10): 3429-3436.

Veeramani, N. M., Hangavel, P. and Ganesan, J. (2005). Genetic variability, heritability and genetic advance analysis in segregating generation of black gram [Vigna mungo (L.) Hepper]. Legume Res., 28 (1): 49-51.

Veni, K., Murugan, E. and Radhamani, T. (2019). Genetic variability in black gram (Vigna munga (L.) Hepper). Acta Hortic., 1241, 275-278.

Vidya, S. R., Sabesan, T. and Saravanak, K., (2018). Genetic divergence study in Black gram (Vigna mungo L.) for yield and quantitative traits. J. Phyto., 10: 2426.

\section{How to cite this article:}

Vikky Kumar, J. L. Salam, Parfull Kumar, N. C. Mandavi and Singh, D.P. 2020. Genetic Parameters of Variation for Seed Yield and its Component Traits in Black Gram (Vigna mungo L. Hepper). Int.J.Curr.Microbiol.App.Sci. 9(10): 1370-1378. doi: https://doi.org/10.20546/ijcmas.2020.910.164 